\title{
The relationship between facet joint osteoarthritis and Modic changes of the lumbar spine: a retrospective magnetic resonance imaging study
}

\author{
Lomber omurganın faset eklem osteoartriti ve Modic değişiklikleri arasındaki ilişki: \\ Retrospektif bir manyetik rezonans görüntüleme çalışması
}

\author{
Mahmut Alpaycı, ${ }_{1}^{1}$ Mehmet Deniz Bulut, ${ }^{2}$ Levent Yazmalar, ${ }^{3}$ Alpaslan Yavuz, ${ }^{2}$ Murat Toprak, ${ }^{1}$ İbrahim Halil Koparan, ${ }^{2}$ Ismail Gülşen ${ }^{4}$ \\ ${ }^{1}$ Department of Physical Medicine and Rehabilitation, Medical Faculty of Yüzüncü Yll University, Van, Turkey \\ ${ }^{2}$ Department of Radiology, Medical Faculty of Yüzüncü Yll University, Van, Turkey \\ ${ }^{3}$ Department of Physical Medicine and Rehabilitation, Medical Faculty of Dicle University, Diyarbakır, Turkey \\ ${ }^{4}$ Department of Neurosurgery, Medical Faculty of Yüzüncü Yll University, Van, Turkey
}

Received / Geliş tarihi: June 2015 Accepted / Kabul tarihi: November 2015

\begin{abstract}
Objectives: This study aims to assess the facet joint osteoarthritis in patients with lumbar Modic changes and to investigate the relationship between the Modic types and severity of the facet joint degeneration.

Patients and methods: A total of 120 patients (55 males, 65 females; mean age $55.18 \pm 9.47$ years; range 40 to 75 years) were included in the study. The patients were divided into four equal groups of 30 patients according to Modic type (No Modic changes, type 1, type 2, type 3 ). All groups were matched with age, sex, and spinal level. A total of 180 lumbar facet joints of the patients with Modic changes (60 facet joints for each Modic type) and 60 lumbar facet joints of the patients without Modic changes were analyzed. The severity of the facet joint osteoarthritis was assessed. The degree of the facet degeneration was evaluated by using the Pathria grading system with magnetic resonance imaging.

Results: Facet joint degeneration increased gradually, as the type of Modic change increased. Compared to the group without Modic changes, all three groups with Modic changes had more degenerative facet joints (all $\mathrm{p} \leq 0.002$ ). The severity of the facet joint degeneration was significantly higher in type 3 versus type 1 Modic changes $(\mathrm{p}=0.022)$.

Conclusion: Our study results suggest that Modic changes, particularly type 3, are strongly associated with the facet joint osteoarthritis of the lumbar spine. Clinically, facet joint degeneration should be considered in the examination of low back pain inpatients with Modic changes.

Keywords: Facet degeneration; lumbar spine; Modic changes; Pathria.
\end{abstract}

$\ddot{O Z Z}$

Amaç: Bu çalışmada, lomber Modic değişiklikleri olan hastalarda faset eklem osteoartriti değerlendirildi ve Modic tipleri ile faset eklem dejenerasyonunun şiddeti arasında ilişki olup olmadığı araştırıldı.

Hastalar ve yöntemler: Çalışmaya toplam 120 hasta (55 erkek, 65 kadın; ort. yaş 55.18 \pm 9.47 yıl; dağılım 40-75 yıl) alındı. Hastalar, Modic tipine (Modic değişikliği yok, tip 1, tip 2, tip 3) göre 30 hastadan oluşan dört eşit gruba ayrıldı. Tüm gruplar yaş, cinsiyet ve spinal seviye açısından eşleștirildi. Modic değișiklikleri olan hastaların toplam 180 lomber faset eklemi (her Modic tipi için 60 faset eklem) ve Modic değișiklikleri olmayan hastaların 60 lomber faset eklemi incelendi. Faset eklem osteoartritinin şiddeti değerlendirildi. Faset dejenerasyonunun şiddeti, Pathria derecelendirme sistemi kullanılarak manyetik rezonans görüntüleme ile derecelendirildi.

Bulgular: Modic değişikliğinin tipi arttıkça, faset eklem dejenerasyonu da giderek arttı. Modic değişiklikleri olmayan gruba kıyasla, Modic değişiklikleri olan üç grupta da, faset eklemler anlamlı düzeyde daha dejeneratif idi (tümü p $\leq 0.002$ ). Tip 1 Modic değişikliklere kıyasla, tip 3 Modic değişiklikleri olan gruptaki faset eklem dejenerasyonunun şiddeti anlamlı düzeyde daha yüksek bulundu ( $\mathrm{p}=0.022)$.

Sonuç: Çalışma sonuçlarımız, başta tip 3 olmak üzere, Modic değişikliklerinin lomber omurgadaki faset eklem osteoartriti ile güçlü bir şekilde ilişkili olduğunu göstermektedir. Klinik olarak, Modic değişiklikleri olan hastalarda bel ağrısı değerlendirilirken, faset eklem dejenerasyonu da göz önünde bulundurulmalıdır.

Anahtar sözcükler: Faset dejenerasyonu; lomber omurga; Modic değişiklikleri; Pathria.

Corresponding author / İletişim adresi: Mahmut Alpaycı, MD. Yüzüncü Yll Üniversitesi Dursun Odabaş Tip Merkezi, Fiziksel Tip ve Rehabilitasyon Kliniği 65080, Van, Turkey. e-mail / e-posta: mahmutalpayci@gmail.com 
Modic changes (MCs) are defined as vertebral endplate and bone marrow signal intensity changes visible on magnetic resonance imaging (MRI) ${ }^{[1]}$ These MRI findings are generally classified into three different types, according to their signal patterns on $T_{1}$ and $T_{2}$-weighted sequences (Table 1, Figures 1, 2, and 3). In addition, the histopathological features of MCs have been described (Table 1). ${ }^{[1,2]}$ The underlying pathophysiological mechanisms for development of MCs are not completely clarified, but abnormal load and mechanical stress, local inflammation and focal bacterial infection secondary to degenerative disc or an autoimmune reaction are proposed mechanisms. ${ }^{[3-5]}$ Modic changes are clinically associated with low back pain. ${ }^{[6]}$

Osteoarthritis of the facet joints is considered one of the most common causes of chronic low back pain. ${ }^{[7]}$ The facet joints are synovial joints of the spine, and osteoarthritis of the facet joints shows similarity to that of all the diarthrodial joints. ${ }^{[8]}$ Although the primary risk factor of the disorder is advanced age, because of the high level of mobility and load forces in the lumbar region, facet joint osteoarthritis becomes more apparent in this spinal region. ${ }^{[8,9]}$

Both an association between facet joint osteoarthritis and disc degeneration and an association between disc degeneration and MCs have been demonstrated in previous studies. ${ }^{[2,7,10]}$ Accordingly, to assert that MCs may be associated with facet joint osteoarthritis is reasonable. To the best of our knowledge, no study has investigated facet joint osteoarthritis in patients with MCs. Therefore, in this retrospective MRI study, we aimed to evaluate facet joint osteoarthritis in patients with MCs.

\section{PATIENTS AND METHODS}

The study protocol was approved by the Ethics Committee of Yüzüncü Yıl University (Decision No: 04; Date: 27 February 2014). We collected retrospective data from MRI images of 120 patients (55 males, 65 females; $55.18 \pm 9.47$ years; range 40 to 75 years) with low back pain at our hospital between January 2013 and January 2014. The patients were divided into four equal groups of 30 patients according to Modic type (No MCs, type $1 \mathrm{MCs}$, type $2 \mathrm{MCs}$, type $3 \mathrm{MCs}$ ). The study was conducted in accordance with the principles of the Declaration of Helsinki. Lumbar MRI findings including MCs were analyzed in terms of osteoarthritis severity of the right and left facet joints at the same level of MCs. Each facet joint was graded in agreement by two radiologists using the Pathria grading scale (Table 2, Figure 4). ${ }^{[10]}$

We tried to select groups that were as similar as possible in terms of age, sex, and spinal levels so we could fairly compare the severity of facet joint osteoarthritis. In order to evaluate the severity of facet joint osteoarthritis, a total of 180 lumbar facet joints from lumbar MRI images of patients with MCs (60 facet joints for each Modic type), and 60 lumbar facet joints from MRI images of patients without MCs were selected and analyzed. The age range of the analyzed patients was limited to ages 40 to 75 . All patients whom MRI scans were included in this study had low back pain. The images of patients with spine neoplasm, spine infections such as brucellosis, tuberculosis, abscess, and spine curvature disorders such as scoliosis were excluded from the study.

All images were obtained from a 1.5-T MRI system (Siemens Magnetom Symphony, Erlangen, Germany) with a spinal coil. The imaging protocol contained $\mathrm{T}_{1}$-weighted spin-echo sequences (560/10/90/2 [TR/TE] $)$ and axial and sagittal $\mathrm{T}_{2}$-weighted turbo spin-echo sequences (3480/102).

\section{Statistical analysis}

Statistical analyses were carried out using the SPSS for Windows version 13.0 (SPSS Inc., Chicago, IL, USA) software program. The descriptive statistics were presented as mean \pm standard deviation or by the number of cases. The normality of the distribution of continuous variables was determined via a one-sample Kolmogorov-Smirnov test. The ANOVA test was used for the group that displayed a normal distribution, and Kruskal-Wallis test and Mann-Whitney $U$ test were used for the group that did not display a normal distribution. The categorical variables were evaluated by chi-square test. A $p$ value of $<0.05$ was considered

Table 1. Magnetic resonance imaging characteristics and histopathological findings of Modic changes

\begin{tabular}{lccc}
\hline & Type 1 MCs & Type 2 MCs & Type 3 MCs \\
\hline $\mathrm{T}_{1}$-weighted imaging & Hypointense signal & Hyperintense signal & Hypointense signal \\
$\mathrm{T}_{2}$-weighted imaging & Hyperintense signal & Hyperintense signal & Hypointense signal \\
Histopathological findings & $\begin{array}{c}\text { Bone marrow edema } \\
\text { and inflammation }\end{array}$ & Fatty replacement of bone marrow & Subchondral bone sclerosis \\
& & & \\
& & &
\end{tabular}



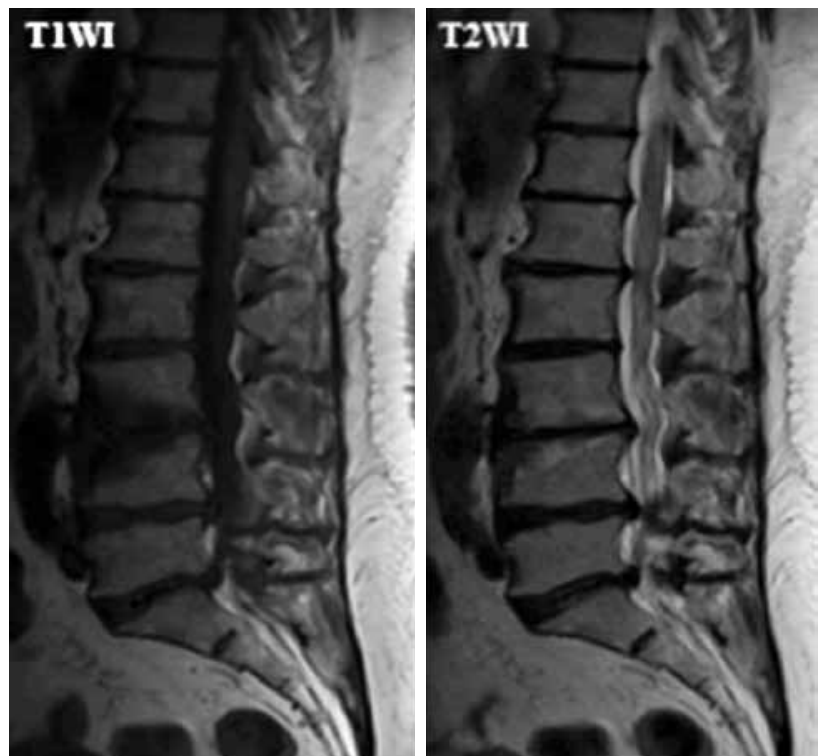

Figure 1. Type 1 Modic changes are hypointense on $\mathrm{T}_{1}$-weighted imaging $\left(\mathrm{T}_{1} \mathrm{WI}\right)$ and hyperintense on $\mathrm{T}_{2} \mathrm{WI}$.

to be statistically significant. The sample size was calculated via G*Power V.3.1.7 (Heinrich Heine University, Dusseldorf, Germany) statistical software package. The severity of facet joint degeneration was evaluated by comparing the change in primary outcome measures between the two groups. The mean difference in the severity of facet joint degeneration
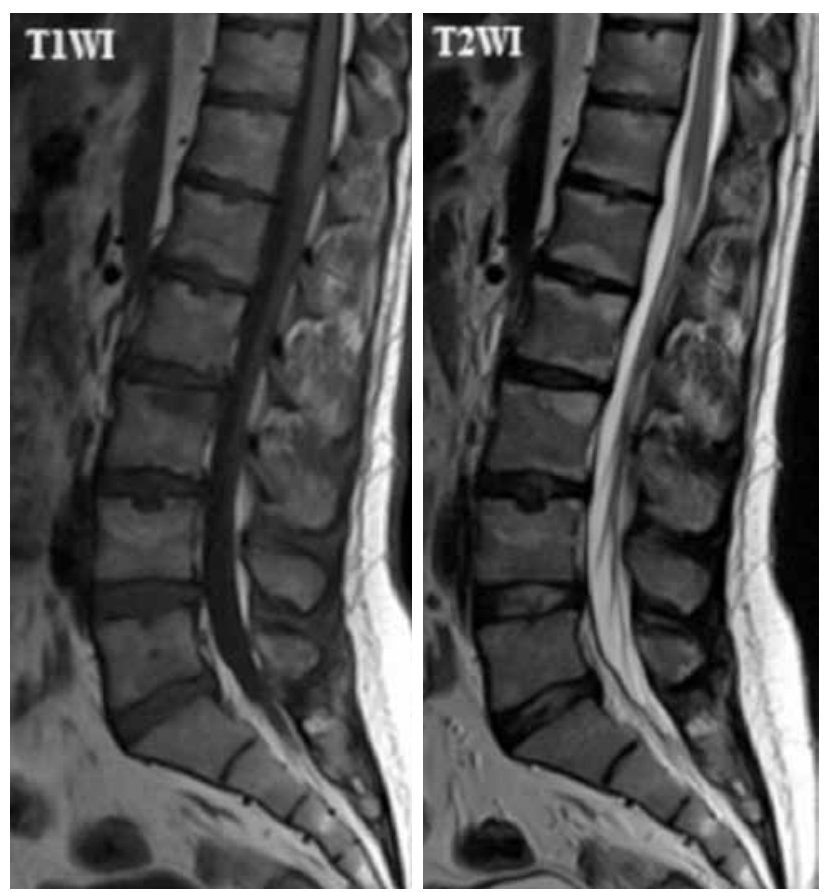

Figure 2. Type 2 Modic changes are hyperintense on $\mathrm{T}_{1}$-weighted imaging $\left(\mathrm{T}_{1} \mathrm{WI}\right)$ and hyperintense on $\mathrm{T}_{2} \mathrm{WI}$. was 0.72 . For the given effect size 0.455368 (group means of $2.3 \pm 2$ and $1.6 \pm 1$ ) and, alpha (0.05), the power was 0.80 at the sample size of 61 .

\section{RESULTS}

The demographic characteristics of the study groups are shown in Table 3. There were no significant differences among the four groups in terms of age, sex or spinal levels of MCs (all $\mathrm{p}>0.05$ ). The mean value of the facet degeneration grade in the group without MCs was $1.6 \pm 0.6$, in each group with MCs was $2.0 \pm 0.8$ for type $1,2.1 \pm 0.6$ for type $2,2.3 \pm 0.8$ for type 3. The comparisons of all four groups in terms of the severity of facet joint degeneration, according to the Pathria grading scale, is presented in Table 4. Considering the severity of facet joints degeneration, significant differences were found between the groups without and with MCs (all $\mathrm{p}<0.05)$. In the three groups with MCs, the severity of facet joint degeneration was significantly greater than in the group without MCs (all $\mathrm{p} \leq 0.002$ ). Also, compared with the facet joints of type $1 \mathrm{MCs}$, those of type $3 \mathrm{MCs}$ were significantly more degenerative $(\mathrm{p}<0.022)$.

\section{DISCUSSION}

In this study, we retrospectively evaluated using MRI the severity of facet joint osteoarthritis in patients
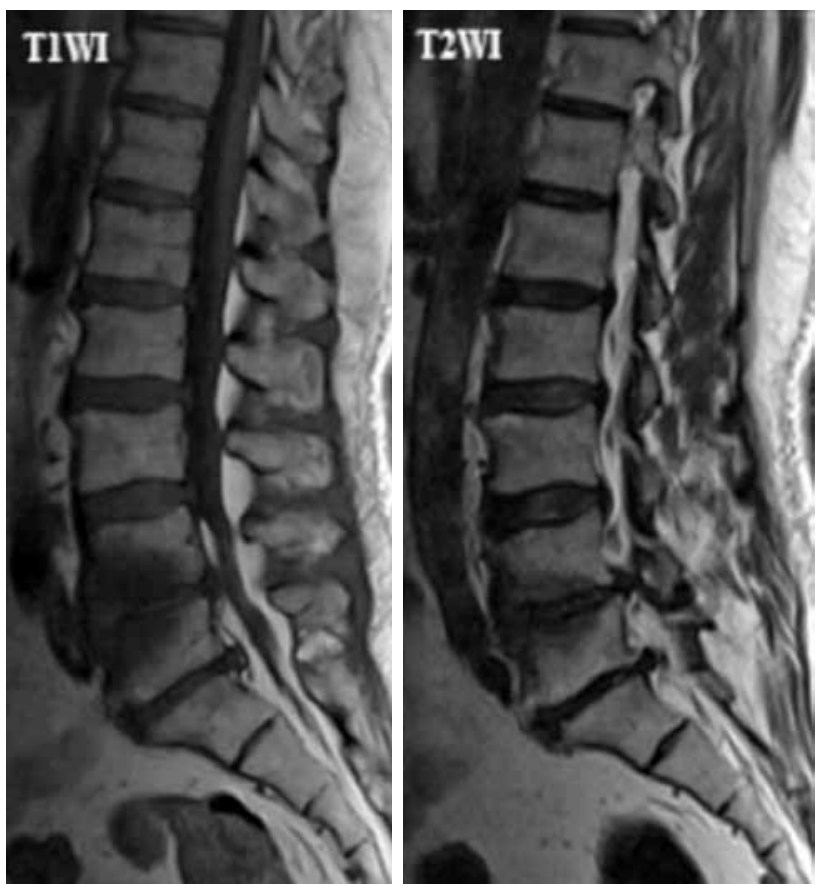

Figure 3. Type 3 Modic changes are hypointense on $\mathrm{T}_{1}$-weighted imaging $\left(\mathrm{T}_{1} \mathrm{WI}\right)$ and hypointense on $\mathrm{T}_{2} \mathrm{WI}$. 
Table 2. Pathria's criteria for the grading of facet joint degeneration

\begin{tabular}{lll}
\hline Grade 1 & Normal & No degeneration findings \\
Grade 2 & Mild & Joint space narrowing or mild osteophyte \\
Grade 3 & Moderate & Sclerosis or moderate osteophyte \\
Grade 4 & Severe & Marked osteophyte or subchondral cyst \\
\hline
\end{tabular}

with lumbar MCs using the Pathria grading system. The study results demonstrated that the groups with MCs, especially type 3 , had more degenerative facet joints compared to the control group without those lesions. That is, the coexistence of these two disorders may not be coincidental and patients with MCs are more likely to have a facet joint osteoarthritis at the same spinal level.

Histopathological studies have demonstrated that type $1 \mathrm{MCs}$ are detected in areas with inflammation, type 2 MCs are detected in areas with fatty degeneration, and type 3 MCs are detected in areas with sclerosis. ${ }^{[1,2,11]}$ These histopathological features of MCs suggest that type 1 MCs are early period, while type $3 \mathrm{MCs}$ are late period of degenerative processes. Similarly, our results show that the severity of facet joint degeneration increases steadily as the type of MC increased (Table 4 and Figure 5). These findings support that there is a strong relationship and correlation between facet joint osteoarthritis and MCs.

In previous studies, $\mathrm{Li}$ et $\mathrm{al}^{\left[{ }^{[7]}\right.}$ and Fujiwara et al. ${ }^{[10]}$ have found that intervertebral disc degeneration precedes and promotes facet joint osteoarthritis. $\mathrm{Yu}$ et al $^{[2]}$ also have found MCs correlate closely with intervertebral disc degeneration. Therefore, a relationship between MCs and facet joint osteoarthritis is an expected and logical finding. In addition, given that degenerative diseases are related to disrupted biomechanics and increased loading condition, it can be said that all of the anatomical structures in the same spinal motion segment may have been damaged by degenerative processes. Because both are degenerative processes, ${ }^{[8,9,12]}$ facet joint osteoarthritis and MCs may be concomitant at the same spinal level. Moreover, since spontaneous resorption of lumbar disc herniation is less likely when MCs are present, ${ }^{[13]}$ similarly, the presence of MCs may also have prognostic value in facet joint osteoarthritis. The results of the present study corroborate these assertions.

Most of the studies associated with MCs have focused on the relationship between MCs and low-back pain. Modic changes and facet joint osteoarthritis are both thought to be potential sources of chronic low back pain but it is not known if patients with MCs also have a specific clinical manifestation. ${ }^{[14]}$ On the other hand, clinical profile of facet joint mediated pain is more detailed..$^{[8,9]}$ Nevertheless, no physical examination tests are pathognomonic for symptomatic facet degeneration..$^{[9]}$ For this reason, pain related to MCs may be difficult to differentiate from pain originating from facet joint osteoarthritis, and the coexistence of these two disorders in the same patient may be the cause of persistent low back pain.

Clinically, our study suggests that the facet joints at the spinal levels with MCs should be evaluated carefully because MCs may be a sign of facet joint degeneration. Perhaps the source of low back pain is facet joint degeneration in patients with MCs. Consistent with this, Bianchi et al. ${ }^{[15]}$ reported that the presence of MCs may be related to improvement in patients undergoing imaging-guided lumbar facet injection therapy, and there is a tendency for patients without MCs to have
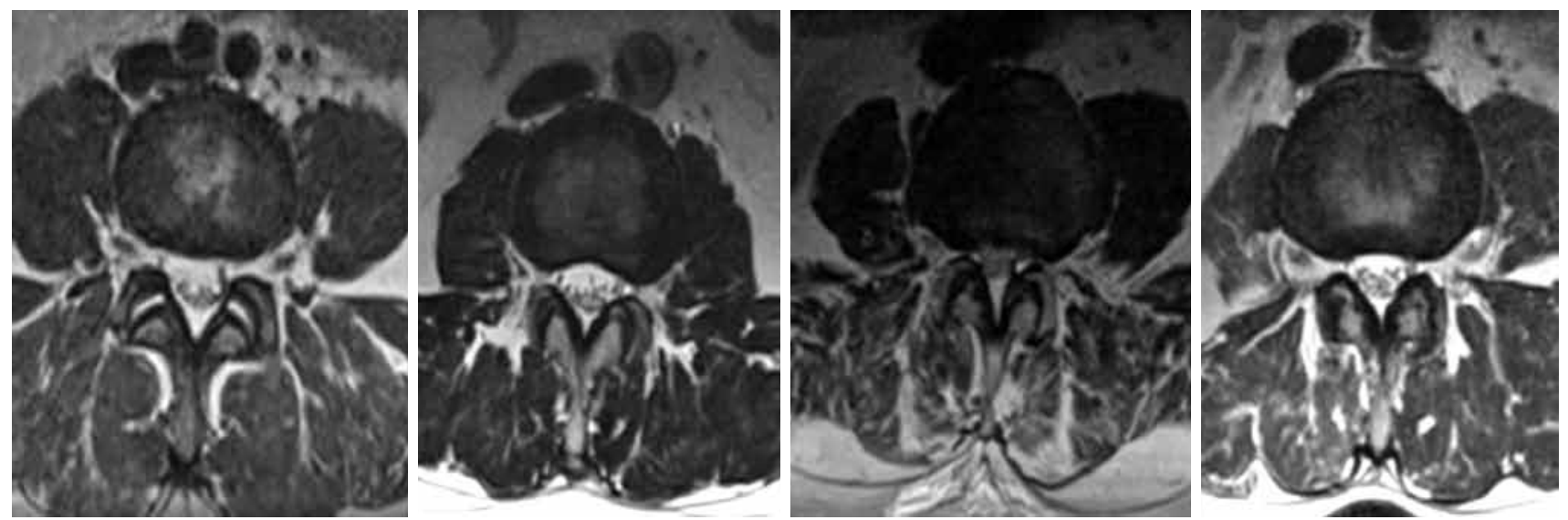

Figure 4. The degree of facet joint degeneration, according to Pathria's criteria. 
Table 3. Groups' characteristics for age, gender, and spinal levels of Modic changes

\begin{tabular}{|c|c|c|c|c|c|c|c|c|c|}
\hline & \multicolumn{2}{|c|}{ No MCs $(n=30)$} & \multicolumn{2}{|c|}{ Type 1 MCs $(n=30)$} & \multicolumn{2}{|c|}{ Type 2 MCs $(n=30)$} & \multicolumn{2}{|c|}{ Type 3 MCs $(n=30)$} & \multirow[b]{2}{*}{$p$} \\
\hline & $\mathrm{n}$ & Mean \pm SD & $\mathrm{n}$ & Mean \pm SD & $\mathrm{n}$ & Mean \pm SD & $\mathrm{n}$ & Mean \pm SD & \\
\hline Age (years) & & $55.4 \pm 9.8$ & & $55.7 \pm 10.0$ & & $54.4 \pm 10.1$ & & $55.3 \pm 8.3$ & 0.957 \\
\hline Gender & & & & & & & & & 0.947 \\
\hline Female & 15 & & 17 & & 17 & & 16 & & \\
\hline Male & 15 & & 13 & & 13 & & 14 & & \\
\hline Spinal levels & & & & & & & & & 0.999 \\
\hline L2-L3 & 5 & & 5 & & 4 & & 5 & & \\
\hline L3-L4 & 6 & & 5 & & 5 & & 7 & & \\
\hline L4-L5 & 9 & & 11 & & 10 & & 9 & & \\
\hline L5-S1 & 10 & & 9 & & 11 & & 9 & & \\
\hline
\end{tabular}

MCs: Modic changes; SD: Standard deviation.

Table 4. Groups' comparisons for the severity of facet joint degeneration

\begin{tabular}{|c|c|c|c|c|c|c|c|c|c|c|c|c|c|}
\hline & \multicolumn{3}{|c|}{$\begin{array}{l}\text { The facets without } \\
\text { MCs }(\mathrm{n}=60)\end{array}$} & \multicolumn{3}{|c|}{$\begin{array}{l}\text { The facets with type } 1 \\
\text { MCs }(\mathrm{n}=60)\end{array}$} & \multicolumn{3}{|c|}{$\begin{array}{c}\text { The facets with type } 2 \\
\text { MCs }(n=60)\end{array}$} & \multicolumn{3}{|c|}{$\begin{array}{c}\text { The facets with type } 3 \\
\text { MCs }(\mathrm{n}=60)\end{array}$} & \multirow[b]{2}{*}{$p$} \\
\hline & Mean $\pm S D$ & Median & Min.- Max. & Mean \pm SD & Median & Min.- Max. & Mean $\pm S D$ & Median & Min.- Max. & Mean \pm SD & Median & Min.- Max. & \\
\hline SFJD & $1.6 \pm 0.6$ & 1.00 & $1-3$ & $2.0 \pm 0.8$ & 2.00 & $1-4$ & $2.1 \pm 0.6$ & 2.00 & $1-4$ & $2.3 \pm 0.8$ & 2.00 & $1-4$ & $\begin{array}{c}0.002^{*} \\
<0.001^{* *} \\
<0.001 \% \\
0.287 \dagger \\
0.022 \S \\
0.116\end{array}$ \\
\hline
\end{tabular}

MCs: Modic changes; SD: Standard deviation; Min.: Minimum; Max.: Maximum; SFJD: Severity of facet joints degeneration; ${ }^{\star}$ Comparison between the facets without MCs and the facets with type $1 \mathrm{MCs} ;{ }^{* *}$ Comparison between the facets without MCs and the facets with type $2 \mathrm{MCs}$; Comparison between the facets without MCs and the facets with type $3 \mathrm{MCs}$ $\uparrow$ Comparison between the facets with type $1 \mathrm{MCs}$ and the facets with type $2 \mathrm{MCs} ; \S$ Comparison between the facets with type $1 \mathrm{MCs}$ and the facets with type 3 MCs; 9 Comparison between the facets with type 2 MCs and the facets with type 3 MCs.

better outcomes. Moreover, a recent study revealed that MCs are significantly related to decreased angular motion and increased translational motion in the lumbar spine. ${ }^{[11]}$ In accordance with these findings and our study results, it can be suggested that the reason for the decreased angular motion and increased translational motion may be related to facet joint degeneration as well as disc degeneration.

Many risk factors have been proposed to contribute to the development of facet joint osteoarthritis, including, for example, advanced age, female gender,

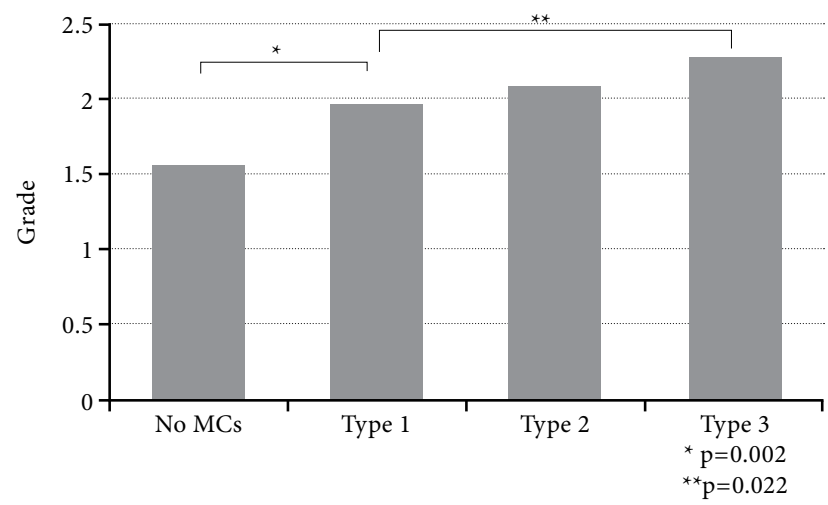

Figure 5. The average Pathria grades of the facet joints in the different groups. MCs: Modic changes. and lumbar spinal level. ${ }^{[8,9]}$ Therefore, in the design of the present study we selected similar groups in terms of these factors. The results of the study suggest that the presence of MCs also may be an independent risk factor for the occurrence of facet joint osteoarthritis. However, it is a retrospective study, and the lack of sufficient information about patient characteristics such as obesity, physical trauma, occupational factors, and smoking, which are known risk factors for facet joint osteoarthritis, ${ }^{[8,9]}$ is an important limitation of the study. Another limitation in this study is that MRI findings were used for the assessment of facet joint osteoarthritis. Even though the best method for the evaluation of facet joints is computed tomography, ${ }^{[8]}$ Weishaupt et al. ${ }^{[16]}$ found that there is moderate to good agreement between MRI and computed tomography in the assessment of lumbar facet joint osteoarthritis.

In conclusion, besides their significance in causing low back pain, MCs may be a valuable radiological sign of facet joint degeneration. Clinically, facet joint osteoarthritis should be taken into consideration when evaluating low back pain in patients with MCs.

\section{Declaration of conflicting interests}

The authors declared no conflicts of interest with respect to the authorship and/or publication of this article. 


\section{Funding}

The authors received no financial support for the research and/or authorship of this article.

\section{REFERENCES}

1. Rahme R, Moussa R. The modic vertebral endplate and marrow changes: pathologic significance and relation to low back pain and segmental instability of the lumbar spine. AJNR Am J Neuroradiol 2008;29:838-42.

2. Yu LP, Qian WW, Yin GY, Ren YX, Hu ZY. MRI assessment of lumbar intervertebral disc degeneration with lumbar degenerative disease using the Pfirrmann grading systems. PLoS One 2012;7:48074.

3. Albert HB, Kjaer P, Jensen TS, Sorensen JS, Bendix T, Manniche C. Modic changes, possible causes and relation to low back pain. Med Hypotheses 2008;70:361-8.

4. Arndt J, Charles YP, Koebel C, Bogorin I, Steib JP. Bacteriology of degenerated lumbar intervertebral disks. J Spinal Disord Tech 2012;25:211-6.

5. Wilkens P, Storheim K, Scheel I, Berg L, Espeland A. No effect of 6-month intake of glucosamine sulfate on Modic changes or high intensity zones in the lumbar spine: subgroup analysis of a randomized controlled trial. J Negat Results Biomed 2012;11:13.

6. Alpayci M, Balbaloglu O, Kandemir A. Brucella serology in patients with low back pain with Modic type II lesion. Nobel Med 2014;10:55-8.

7. Li J, Muehleman C, Abe Y, Masuda K. Prevalence of facet joint degeneration in association with intervertebral joint degeneration in a sample of organ donors. J Orthop Res
2011;29:1267-74.

8. Kalichman L, Hunter DJ. Lumbar facet joint osteoarthritis: a review. Semin Arthritis Rheum 2007;37:69-80.

9. Gellhorn AC, Katz JN, Suri P. Osteoarthritis of the spine: the facet joints. Nat Rev Rheumatol 2013;9:216-24.

10. Fujiwara A, Tamai K, Yamato M, An HS, Yoshida H, Saotome $\mathrm{K}$, et al. The relationship between facet joint osteoarthritis and disc degeneration of the lumbar spine: an MRI study. Eur Spine J 1999;8:396-401.

11. Hayashi T, Daubs MD, Suzuki A, Scott TP, Phan KH, Ruangchainikom $M$, et al. Motion characteristics and related factors of Modic changes in the lumbar spine. J Neurosurg Spine 2015;22:511-7.

12. Jensen RK, Leboeuf-Yde C. Is the presence of modic changes associated with the outcomes of different treatments? A systematic critical review. BMC Musculoskelet Disord 2011;12:183.

13. Shan Z, Fan S, Xie Q, Suyou L, Liu J, Wang C, et al. Spontaneous resorption of lumbar disc herniation is less likely when modic changes are present. Spine (Phila $\mathrm{Pa}$ 1976) 2014;39:736-44.

14. Kjaer P, Korsholm L, Bendix T, Sorensen JS, Leboeuf-Yde C. Modic changes and their associations with clinical findings. Eur Spine J 2006;15:1312-9.

15. Bianchi M, Peterson CK, Pfirrmann CW, Hodler J, Bolton J. Are the presence of MODIC changes on MRI scans related to "improvement" in low back pain patients treated with lumbar facet joint injections? BMC Musculoskelet Disord 2015;16:234.

16. Weishaupt D, Zanetti M, Boos N, Hodler J. MR imaging and CT in osteoarthritis of the lumbar facet joints. Skeletal Radiol 1999;28:215-9. 